\title{
CARTOGRAFIA DO MUNDO ATUAL*
}

\author{
Fernand Braudel
}

Cada cidade tem o que contar, seu pequeno discurso para quem se prestar a lhe dar ouvidos. São Paulo é silenciosa, reservada quando se trata de si mesma, falando pouco de seus negócios próprios, um pouco mais interessada pelo Brasil, entretendonos, porém, longamente e com prazer, do mundo. Porque o mundo a envolve, vive com ela, impõe-lhe seu séquito de problemas, de questões e exigências. Já observaram como aqui os intercâmbios intelectuais descrevem grandes círculos e nos fazem viajar pela terra inteira? São Paulo, rosa dos ventos, tem o sentido, a experiência, a compreensão do mundo, não o de ontem, mas o de hoje, cujas coordenadas se contratam, cujo volume diminui, cujos continentes dia-a-dia mais se aproximam uns dos outros. Aqui fermenta a mocidade das coisas; impunemente se pode e deve sonhar com o futuro. Trata-se em verdade da presença real do mundo, tal qual é, tal

\footnotetext{
* Transcrito de $O$ Estado de São Paulo, 19 de Maio de 1935. O trabalho de transcrição e digitação deste e dos demais textos de Braudel aqui publicados foram feitos por: Andrea Zonta, Camila Matheus da Silva (do Departamento de História da UNESP-Assis) e Taise Ferreira da Conceição (Departamento de História da Universidade Estadual de Londrina), a quem agradecemos.
} 
qual se elabora. Vejam-se simplesmente os produtos agrícolas básicos, o café e o algodão; criam entre a propriedade paulista e os mercados mais afastados laços tão reais, e tão fortes, que deles se ocupam diariamente os jornais. Estranha situação esta do fazendeiro do noroeste, que joga sua partida contra adversários da África, Ásia e mesmo da América! Em França, excetuando-se a larga corrente que liga a metrópole às possessões longínquas, tende a economia nacional a fechar-se sobre si mesma, a viver em campo cerrado, razão esta de sua força, sua estabilidade e, também, de sua aparente imobilidade. Em suma, nada nela que se possa comparar a essas intermináveis antenas que vão de São Paulo à Europa, à África do Norte, à América Setentrional, ao pacífico, ao Japão.

Desculpar-me-ão, por isso, ter escutado o conselho repetido da cidade, consagrando meu primeiro artigo para o Estado a essa cartografia do mundo atual, assunto vasto como um cartaz ... desejara dar-lhe o tom de uma simples conversação, em que as idéias, sem programa preestabelecido, vão e vêm e se entrechocam. Não posso esquecer-me, entretanto, de que estou sozinho a falar, a definir minha posição. Felizmente, espero-o, o leitor me seguirá contrariando, criticando o esboço demasiado elementar, que me proponho submeter-lhe, e ajudando-me, assim, a recriar essa atmosfera de contrastes, de vida e discussão, fora da qual não existe conversação aproveitável.

Creio que a carta do mundo é bastante simples. Nela vejo apenas duas divisões: a Europa, no sentido amplo da palavra, e o Extremo Oriente, a Ásia das monções, dos arrozais, dos juncos e terras negras... Estender-me-ei, apenas, sobre o primeiro termo da divisão. Como entender essa Europa dilatada que coloco no primeiro plano de discussão? Defini-la é problema desanimador. Os mais prudentes, que também são os menos francos, falam sem defini-la, do declínio, crise, balanço. Liquida-se a casa, mas quem lhe fixará os limites? A América do Sul? Seria fácil, creio, definir este enorme triângulo cartográfico: mas a Europa? Uma península asiática, disseram, o que não passa de piada. Seu ser geográfico, onde começa e onde acaba? Deverse-ão incluir na sua massa a Inglaterra e seus prolongamentos imperiais, domínios onde reina a libra, e a Rússia, que atinge o Pacífico, e a França de além-mar? Dizia- 
nos um jornalista, há anos, o Sr. Francis Delaisi, que era imprescindível distinguir duas Europas: A Europa A, industrial, povoada de cavalos-vapor, compreendendo a Alemanha, pedaços da Rússia e da Polônia, a Itália Setentrional, a Checoslováquia, a Áustria, a França, os Países Baixos, a Inglaterra e um fragmento da Espanha, e onde a rede das vias férreas e estradas de rodagem aperta suas malhas; e, de outro lado, a Europa B, sem indústria, com suas pistas primitivas, seus campos atrasados, suas ilimitadas reservas de imigração... Escrevia Francis Delaisi no momento em que a Europa, já inquieta procurava uma solução para os problemas de sua existência, propondo-lhe um remédio simples: a formação de um bloco entre as duas Europas, fornecendo um objeto manufaturado à outra, que, em troca, lhe daria seus excessos de trigo e produtos alimentícios. Mais ou menos na mesma época, dizia Lucien Romier coisas semelhantes quando propunha entregar à Alemanha, superpovoada e superindustrializada, a valorização do Far West Europeu. Supondo-se, porém, o que é bastante quimérico, que esse bloco europeu - ameaça em suma para o mundo, pois que constituiria uma potência esmagadora e perigosa para os outros - realizasse sua fusão, reuniria ele toda a substância européia do mundo? Não existirá uma terceira Europa, a Europa C, A Europa Colonial, ou melhor, de além-mar? Não serão Europa também, os Estados Unidos, o Brasil e muitos outros países? A Europa - a velha Europa - conquistou, no passado, o mundo, rompendo-lhe os limites imperfeitos. Só no plano mundial se reconhece sua verdadeira face.

Um esboço econômico do mundo não pode ser mais complicado do que o precedente. Dentro deste novo ponto de vista, surge o universo como um conjunto de reservatórios, de tanques, onde as águas não apresentam o mesmo nível. Referemse os economistas a esta média ideal, o nível dos preços mundiais, realidade aliás, pois é em relação a ele que se efetuam as trocas econômicas, que se organizam marés e correntes e por causa dele se rompem os diques. Esta oceanografia econômica, vista de cima, apresenta aparentemente quatro compartimentos: o continente europeu, o mundo britânico, o fuso americano e a Ásia ou Extremo Oriente. Seja o leitor indulgente e não proteste. Não ignoro as lacunas do esboço e penso, como ele, que 
é sempre no princípio de um raciocínio que se deve protestar e que se encontram as verdades mais contestáveis. Ora, estes compartimentos, que supomos válidos, não se comunicam entre si como os oceanos e mares. Ninguém ignora o duelo da libra contra o dólar, ou do franco contra outra moeda. Daí a imaginar - já se tendo o leitor habituado, não mais protestará - que esses compartimentos representam aparentemente quatro setores, quatro casas rivais, não vai mais que um passo, que é preciso dar. Economicamente falando, as desgraças e dificuldades de um fazem a alegria dos outros. Veja-se a Europa. A inquietação política tornou o futuro incerto no continente, em primeiro lugar. Acresciam às causas gerais da crise fatores psicológicos desfavoráveis. Num país como a França, por exemplo, apesar das tentativas do governo para fazê-los descongelar-se e movimentá-los, os capitais prudentemente se imobilizam e os créditos se restringem. Não terá esta agravação da crise continental relação com o revigoramento dos negócios da Inglaterra? Mas a inquietação européia não poupou, por muito tempo, a ilha. Será necessário a Inglaterra armar-se, proteger-se, sobrecarregando o orçamento... Se a inquietação européia não se dissipar, como lhe é possível, subirá provavelmente a água alhures. Os historiadores não tem, como os homens de negócio, a possibilidade de serem informados diariamente; grave inferioridade! Mas não provirão os leves sintomas da euforia norteamericana do fato de baixarem e se turvarem as águas em outros lugares? Rivalidade mas também solidariedade. Sobem e descem os preços mundiais em virtude de vastos movimentos, marés generalizadas, de que desejariam os economistas fixar a periodicidade e amplidão. Acredita-se na Europa, de preferência, que na pesada atmosfera política do continente está a origem da crise atual; nos Estados Unidos, coloca o presidente Roosevelt, na fonte da maré baixa, a degringolada da economia norteamericana. Não quero pronunciar-me sobre o assunto. Ambas as explicações concordam num ponto, a saber, que o organismo econômico do mundo é uno e um ferimento localizado provoca fatalmente repercussões gerais.

Uma civilização nova, nem sempre visivelmente perceptível se elabora dentro do quadro mundial. Uma civilização vivia, ontem, de alguns empréstimos e de si 
mesma, principalmente de si mesma. Fora do gênio peculiar a um país que a paz enfim readquirida, acalma e encanta, que põe em ação, no século XVII, a vida brilhante que realça os últimos anos do reinado de Henrique IV? Algumas importações de Flandres: Golas de rendas, tijolos para se juntarem as pedras na construção dos muros, e mais outras da prestigiosa Itália ... Hoje, quero repeti-lo, elabora-se uma civilização, feita das mais diversas experiências, que acrescenta aos velhos conceitos da Europa a idéia grandiosa que a América concebeu da máquina, último dos animais domésticos com que o homem se presenteou. Veja-se com que rapidez circulam os mil elementos cuja aglomeração forma uma civilização. Não só as guerras tendem a tornar-se gerais, as modas se irradiam de Paris e Viena através de todos os países e não existe filosofia ou trust que não deseje conquistar o mundo inteiro, nem cidade em que o estilo Le Corbusier não tenha plantado seus modelos.

Nesta sociedade de amanhã, que se elabora, que lugar dar ao sonho, às lições da experiência, ao homem e à máquina? Confesso que este último problema me preocupa aqui mais do que alhures. Nunca apreciei demasiado as pouco compreensíveis Scènes de la Vie Future de Duhamel e agora menos do que nunca. Que prazer, mas que dever também, domar, subjugar a esmagadora natureza americana e lhe impor uma lei humana! Porém é preciso dizê-lo, não existe apenas a natureza por vencer, há, ainda, o terrível labor do homem. A máquina pode ser um escravo e nós os senhores. A civilização - o standard of life - exige repouso e lazer; sem este luxo ela deixa ou quase, de existir. O Renascimento Italiano sem as cortes ociosas dos príncipes mecenas, o Grand Siécle francês, sem a inutilidade da corte, do século XVIII sem os salões das damas ricas demais ... todos estes patrimônios de riqueza intelectual, quanto luxo evocam, quantas aparentes inutilidades sociais! É desolador, para nós e para a sociedade, não tenha a máquina libertado mas sim sujeitado o homem à lei da superprodução. Essas experiências políticas que se elogiam por aí como reclames, eu as julgo sempre perguntando a mim mesmo qual o lugar que assinam ao homem e a máquina. Mas já conversei demais para iniciar o recenseamento dessas experiências atuais... 
Este mundo de que tanto falei, não se pode evitar de sonhá-lo melhor nos seus diferentes planos. Sonhos políticos? Sociedade das Nações, projeto dos Estados Unidos da Europa, idéia de certos escritores ingleses de ligar os países situados em volta do Atlântico num só bloco... Sonhos sociais, econômicos, religiosos... Hesito ante a massa das questões, e, também, a impossibilidade de delimitar problemas. Permitirme-ei, por isso, não para resolver as dificuldades, mas para terminar meu artigo, uma digressão histórica.

Realizou o Império Romano, para o mundo antigo, o sonho que atormenta tantos contemporâneos. Suprimiu as fronteiras, submetendo à mesma lei as pequenas colméias estabelecidas nos bordos do Mediterrâneo. Roma deu aos povos os imensos benefícios da pax romana e a Europa viveu, durante séculos, da lembrança desse paraíso perdido. Levar-se-á sempre em conta, porém, o passivo da experiência romana? Camille Julian a ele fazia alusão em um de seus cursos do Collège de França e eu não resisto ao prazer de bordar algumas considerações nesta grande idéia. Quebrando, com sua conquista, os pequenos mundos independentes, Roma impediu simplesmente o pleno desenvolvimento do pensamento antigo. Viveu como um herdeiro que esbanja a fortuna que não lhe custou amontoar. Antes dela o esplendor do milagre grego; depois dela a Idade Média que a erudição descobre, hoje, ter sido tão fértil no domínio da técnica, quer quanto às estradas, quer quanto à navegação marítima. Roma tendeu para a perfeição política, o mundo de hoje para a perfeição técnica. Não haveria grande perigo em inverter os termos da equação? Não devem uma ordem, uma perfeição ser compradas, ser compensadas por inferioridades flagrantes, misérias inexpiáveis? 